\title{
Sidney Drell resigns from Stanford University centre
}

Berkeley

SIDNEY Drell, the distinguished physicist and arms-control expert, has resigned as co-director of Stanford University's Center for International Security and Arms Control (CISAC), out of frustration over the university's refusal to grant faculty positions at the centre. Drell's leaving will weaken the technical dimension of CISAC's programme, may jeopardize funding and spur an exodus from the centre.

CISAC grew out of an arms-control programme begun in 1970 by Drell, physicist Wolfgang Panofsky and others, and has become a world-famous nuclear arms

\section{Atlantis succeeds \\ Washington}

THE space shuttle Atlantis, carrying a secret military payload, was successfully launched at 9.30 a.m. last Friday, 2 December. The launch had been postponed from Thursday because of strong high-altitude winds, and similar conditions the next day relented only a few minutes before the end of the allotted launch period.

To hinder Soviet attempts to track the shuttle's flight-path, the exact time of blast-off had not been revealed beforehand, and shortly after launch Atlantis turned sharply northwards rather than flying east across the Atlantic Ocean.

The satellite carried by the shuttle was widely reported to be a high-resolution radar imager called Lacrosse, able to map the Earth's surface regardless of weather. In the 21/2-year hiatus before Discovery's flight two months ago, the US Air Force had sent several reconnaissance satellites into orbit using Titan rockets, but in the shuttle's absence the ability of the Department of Defense to follow Soviet military activities had been curtailed.

Atlantis' return to Earth was to be announced with 24 hours' notice, but on Monday 7 December the mission was still in progress with no landing time officially released.

David Lindley

\section{Broder for NCI \\ Washington}

SAmuel Broder, associate director of the clinical oncology programme at the National Cancer Institute, is expected to be named by President Ronald Reagan as the new head of the National Cancer Institute as soon as a necessary background check has been completed. Broder, best known for his work on the AIDS drug AZT, will succeed Vincent DeVita, who left in August. The institute is the United States' largest cancer research facility and has a budget close to $\$ 1,500$ million.

Alun Anderson policy centre under the co-directorship of Drell and Stanford political scientist John Lewis. Most of the 70 CISAC members are Stanford professors, and are only peripherally involved with the centre. But a core of about a dozen senior research associates, including experts on treaty negotiation and weapons systems, work full-time. Stanford's policy of restricting faculty appointments to academic departments has thwarted efforts to secure faculty positions for these people. The result, says Drell, is an unjust situation in which CISAC members are denied professorships, while the fellows they train go on to faculty positions in competing programmes at MIT, Carnegie Mellon and Harvard.

Drell said he resigned because his discussions with Stanford had stalled. He will continue as deputy director of the Stanford Linear Accelerator Center and will pursue his arms-control work through private consultantships.

Stanford provost James Rosse regrets Drell's decision, but defends the university's policy of reserving appointment

\section{Engineering lab privatization postponed}

\section{London}

THE privatization programme of the British government suffered a severe setback last week with the postponement of the sale of the National Engineering Laboratory (NEL). The sale is being delayed for two years while a team of management consultants undertake a study of the laboratory and supervise its restructuring.

The sale, which was announced in June, was planned because most of the work carried out at the laboratory was termed industrially relevant and the government is adamant that the cost of such work is borne by the private sector. Since the government called for commercial bids to be made within six weeks, the sale has been fraught with difficulties.

Nine organizations made bids for the NEL, which is estimated to be worth $£ 30$ million, and negotiations with a Glasgowbased research organization, YARD Limited, took place between August and October, but ended without agreement. The Institution of Professional Civil Servants (IPCS), the union which represents the 300 scientists and technicians at the NEL, says that those negotiations were ended after the Department of Trade and Industry (DTI) realized that it would be illegal to go ahead with the sale because the staff had not been consulted on the reasons for it. Another problem, says the IPCS, was that YARD would have been obliged to take on the current collective power for departments that offer coordinated teaching and doctoral programmes. He says the authority to make faculty appointments could maintain some interdisciplinary programmes beyond their useful lifetimes.

Drell counters that Stanford's inflexibility is a threat to academic quality rather than a safeguard. Academic excellence, he said, is best ensured by conducting national searches, and by broad review of appointments, not by insisting on pigeonholing appointments within departments.

Drell's resignation has prompted the Carnegie Corporation, which has provided CISAC with $\$ 1.8$ million over the past five years, to withhold approval of next year's $\$ 460,000$ grant payment until Stanford provides an assurance that the centre can continue its scientific work in Drell's absence.

Drell warns that several of his younger colleagues, including former astronaut Sally Ride and nuclear engineer Ted Postol, are also likely to leave. Postol says those who leave will not be easily replaced, as there are few scholars with appropriate qualifications. The loss could drive Stanford "out of the business", he said. "It will go from the best programme in the country to no programme."

Marcia Barinaga

bargaining agreements, but that would have been impossible because YARD is a non-union company. And another sticking point was reported to be the amount of funding to be provided by the government during the period of transition into the private sector. At present more than half of the NEL's annual $£ 21$ million funding comes from government: the remainder comes from private industry. Now consultants Touche Ross will carry out a fivemonth study of the NEL, which will be followed by an 18-month period when an advisory body supervises the restructuring.

The IPCS accuses the government of "wreaking mayhem" within the laboratory as a result of its hasty privatization plans, and says that already staff are leaving because of the uncertainty surrounding the NEL's future. Though the government says privatization will still go ahead, another option is to give the laboratory 'agency' status.

Depending on the arrangements surrounding the transfer of public sector institutions to agencies, this can mean anything from an institution remaining almost identical to a private company or, at the other extreme, to part of the civil service. Other candidates for agency status are the remaining DTI establishments: the Laboratory of the Government Chemist, the Warren Spring Laboratory and the National Physical Laboratory.

Christine McGourty 